\title{
School Leader Development: Current Trends from a Global Perspective
}

\section{Stephan Gerhard Huber}

This article looks at the growing importance placed on activities to prepare school leaders in correspondence to their central role for de-veloping and assuring the quality of schools and the ever-increasing responsibilities they are facing. In many countries, this has led to the design and implementation of extensive programs. In this paper, an overview of predominant approaches in use across Europe, Asia, Aus-tralasia, and North America is provided, and international trends in school leader development are identified. It becomes obvious that the aims of school leader development programmes should be grounded on a more broadly defined understanding of leadership, adjusted to the core purpose of school, and based on educational beliefs integrating the values of a democratic society.

In view of the ever-increasing responsibilities of school leaders ${ }^{1}$ for ensuring the quality of schools, school leadership has recently become one of the central concerns of educational policy makers. In many countries, the development of school leaders is high on the agenda of politicians of different political wings. At the turn of the century, there is broad international agreement about the need for school leaders to have the capacities needed to improve teaching, learning, and pupils' development and achievement.

At first sight, there may appear to be an international consensus about the important role of school leaders and their development. On looking more carefully, however, it is apparent that a number of countries have engaged in this issue more rigorously than others. While in some countries discussions of school leader development are mainly rhetoric, elsewhere concrete steps have been taken to provide significant development opportunities for school leaders. Hence, a comparison of school leadership development opportunities in different countries is instructive. 
This chapter draws on data from an international study of school leadership development (see Huber, 2002, 2003).

The comparative research project was conducted in the years 1998-2001. Its methodical approach corresponds to that of the systematic procedures of comparative educational research; the individual steps can be illustrated accordingly: the research question was first of all operationalised. Then, the sample countries and programs were selected. However, the sample was not restricted at the first stage of the study, but was based on the accessibility of information, which depends on language conditions as well as on contacts to experts and persons in charge in the respective countries. Methods of data collection comprised international literature research, expert meetings, systematic collection of documents, a systematic questionnaire developed for this study, open and non-directive questioning, and additional research via telephone and email. The data was screened, sorted, selected according to a classification scheme, systematised in several steps, and was then presented in a matrix, which allowed a systematic comparison.

The analysis resulted in country or program descriptions, which in turn were modified in several steps. An additional validation of the country and program descriptions by renewed feedback from the expert of the respective country was carried out. This educationalist was invited to be the co-author of the country report.

The report surveys the development models for school leaders in the countries included in the study. Even though minor changes and developments may have occurred in some of the countries since the collection of data, the trends depicted here represent international patterns in school leadership development. On their basis, comparisons can be made and recommendations for the design of future development programs can be given.

Considering the various approaches, concepts, and macro- and micro-didactic realisations of development opportunities for school leaders, research into the effectiveness of the individual programs would be of central importance. This, however, could not be achieved by this study for various reasons (in detail see Huber, 2003). Generally speaking, studies that determine effectiveness continue to be something that is needed. Evaluations that consider a range of programs or even international, comparative studies of effectiveness are completely non-existent. This may be partly due to the fundamental problems that arise whenever attempts at evaluating the "effectiveness» of the teaching and learning processes in development programs are made. Nevertheless, considering the high costs that are often associated with development programs (also for the participating candidates), efforts at evaluating program effectiveness would be of major importance. This seems particularly relevant, as in more and more countries, school leadership is seen as essential for assuring the quality of schools. An exploratory international comparison like this, however, is the conditio sine qua non for extended research into the efficiency of such programs. 


\section{Approaches to School Leadership Development: An Overview of International Efforts}

The following table summarizes school leadership development models in 15 countries. It is meant to provide an accessible overview of predominant approaches in use across Europe, Asia, Australasia, and North America.

\section{Table 1. Overview of Current Approaches to Develop School Leaders}

\begin{tabular}{|l|}
\hline \multicolumn{1}{|c|}{ Europe } \\
\hline $\begin{array}{l}\text { Denmark } \\
\text { Optional offers made by municipalities, universities and private suppliers without any central framework } \\
\text { or delivery system }\end{array}$
\end{tabular}

\section{Sweden}

A national preparatory programme offered by universities through a basic course plus additional offers by the municipalities

\section{England and Wales}

A centrally organised programme delivered by regional training centres; combines assessment and training with a competency-based and standards-driven approach; the programme is embedded in a threephase training model

France

A mandatory, centrally-designed, intensive, full-time, half-year preparation programme with internship attachment for candidates who have successfully passed a competitive selection process; completion guarantees a leadership position on probation (during which further participation in training is required)

\section{Netherlands}

A broad variety of different optional preparatory and continuous development programmes by different providers (e.g., universities, advisory boards, school leadership associations) in an education market characterised by 'diversity and choice'

\section{Germany}

Courses conducted by the state-run teacher training institute of the respective State, mostly after appointment; differs from State to State in terms of contents, methods, duration, structure, and extent of obligation

\section{Austria}

Mandatory centrally-designed, modularised courses post-appointment; delivered by the educational institute of each State; required for continued employment after four years

\section{Switzerland}

Quasi-mandatory, canton-based, modularised programmes offered post- appointment; delivered by the respective provider of the canton, most often the teacher training institute, wherein the aim is nationwide accreditation (national standards are currently being developed)

\section{South Tyrol, Italy}

A mandatory programme for serving school leaders to reach another salary level as becoming 'Diricente'; delivered by a government-selected provider that combines central, regional, and small group events with coaching attachment 


\section{Singapore}

A mandatory, centrally-controlled, preparatory, nine-month, full-time programme provided through a university; comprised of seminar modules and school attachments

Hong Kong, China

A centrally-designed, mandatory, nine-day, content-based induction course immediately after taking over the leadership position

\begin{tabular}{|l|}
\hline \multicolumn{1}{|c|}{ Australasia } \\
\hline $\begin{array}{l}\text { New South Wales, Australia } \\
\text { An optional, modularised, three-phase programme offered by the Department for Education; centrally- } \\
\text { designed, yet conducted decentralized via regional groups; besides there are offers by independent pro- } \\
\text { viders }\end{array}$ \\
\hline $\begin{array}{l}\text { New Zealand } \\
\text { A variety of programmes with themation in contents, methods and quality; conducted by independent } \\
\text { providers, but also by institutes linked to universities; no state guidelines, standards or conditions for li- } \\
\text { censure }\end{array}$ \\
\hline
\end{tabular}

\begin{tabular}{|l|}
\hline \multicolumn{1}{|c|}{ North America } \\
\hline $\begin{array}{l}\text { Ontario, Canada } \\
\text { Mandatory, preparatory, university-based, one-year, part-time programme delivered through several ac- } \\
\text { credited universities following a framework given by the 'College of Teachers' (the self-regulatory body } \\
\text { of the profession) }\end{array}$ \\
\hline USA: \\
Washington \\
New Jersey \\
California \\
Mandatory, intensive, preparatory, one-year, university programmes that include extensive internship at- \\
tachments; programmes use a broad variety of instructional methods
\end{tabular}

Although this table merely provides an overview, a broad variety of school leader development approaches is recognizable. In spite of differences in cultural and institutional traditions, there are common tendencies and trends across these countries. While some of them may be viewed as differences in emphasis, others may be so large as to represent paradigm shifts. The largest differences are evident in those countries that have longer experience in school leader development and school leadership research. This chapter focuses on nine of these tendencies, trends, and shifts (for a fuller account see Huber, 2003). These include:

1. Central quality assurance and decentralized provision;

2. Preparatory training and development;

3. Comprehensiveness of programmes;

4. Multi-phase designs and modularisation;

5. From administration and maintenance to leadership for improvement;

6. Developing the leadership capacity of schools;

7. From acquisition to creation and development of knowledge;

8. From role-based training to personal, professional development;

9. New leadership conceptions and an orientation towards values. 


\section{Central quality assurance and decentralized provision of programmes}

As shown in Table 1, provision of development opportunities for school leaders varies broadly across the countries. There are different degrees of centralization and decentralization with regard to how much choice prospective participants have over available providers and development programmes. Here, the interrelation between the qualification approach and the educational policy and school system background is of particular interest. The countries can be categorized in terms of these two dimensions (see Table 2).

Table 2. Centralization and Decentralization of School Systems and School Leader Development

\begin{tabular}{|c|c|c|c|c|c|}
\hline & & & \multicolumn{3}{|c|}{ Approach to School Leader Development } \\
\hline & & & $\begin{array}{l}\text { Predominantly } \\
\text { Centralized or } \\
\text { Using Standards or } \\
\text { Guidelines }\end{array}$ & & Entrepreneurial \\
\hline \multirow{2}{*}{$\begin{array}{l}\text { Level of } \\
\text { Central } \\
\text { Control over } \\
\text { School } \\
\text { Management }\end{array}$} & $\begin{array}{l}\text { Predominantly } \\
\text { Centralized }\end{array}$ & A & $\begin{array}{l}\text { France; } \\
\text { South Tyrol; } \\
\text { Austria; } \\
\text { Germany; } \\
\text { Hong Kong; } \\
\text { Singapore }\end{array}$ & B & \\
\hline & $\begin{array}{l}\text { Substantially } \\
\text { Devolved }\end{array}$ & $\mathrm{C}$ & $\begin{array}{l}\text { Ontario, Canada; } \\
\text { USA*; } \\
\text { NSW, Australia; } \\
\text { Sweden; } \\
\text { England and Wales; } \\
\text { Switzerland }\end{array}$ & & $\begin{array}{l}\text { Denmark; } \\
\text { Netherlands; } \\
\text { USA*; } \\
\text { New Zealand }\end{array}$ \\
\hline
\end{tabular}

* Double listing is due to differences in the approaches of the different States

In some centrally organised school systems (see Table 2, Cell A), there is a centrally regulated development programme. It has a standardized approach and its delivery is centrally organised. The programme is mandatory for all school leaders. In contrast, in some decentralized school systems (see Cell D), there are a variety of programmes offered by competing providers. The choice of which programme(s) to attend is up to the individual (aspiring) school leader. Here, the governments abstain from any regulation or control of professional development. Countries with a predominantly centralised school system and with an entrepreneurial approach to school leader development could - not too much surprisingly - not be found in the study.

Another existing themant, however, is represented by countries with decentralized school systems (see Cell C), whose programmes are designed according to central guidelines, but are not standardized in every detail. Their general approach seems particularly progressive and pioneering. Teachers who want to 
qualify for a leadership position can choose among various service suppliers with assurance that the programme is accepted and recognized by the state and/or employing bodies. In North American countries, responsibility for designing and conducting qualification programmes lies primarily with universities (e.g., Ontario, Canada as well as in the US examples included in the study). However, these universities are not completely independent when setting up their development programmes. They must take centrally developed goals and standards into account.

Most recently in the US, a cross-state «catalogue» of standards has been set up by the Interstate School Leaders Licensure Consortium (ISLLC; cf. Murphy $\&$ Shipman). This has been approved by the Council of Chief State School Officers (CCSSO) and by 36 States. Washington and New Jersey, for example, grant state certificates for the participants after completing the development courses based on those standards. This is the case even though - due to the decentralized character of the American school system - selection and employment of school leaders remain the responsibility of local committees. In Ontario, the self-regulatory body of the teaching profession, the Ontario College of Teachers (OCT), has established guidelines for development of school leaders. Only universities accredited by this body may offer the development programme. In Europe as well, some other countries are moving towards assuring quality by centrally regulating qualifications for school leadership positions. For instance, in England and Wales, a central institution, the National College for School Leadership (NCSL) has been established (cf. Bolam; cf. Tomlinson). This institute is responsible for designing and conducting all national development opportunities for school leaders.

A fundamental level of quality assurance is undoubtedly important to participants, as is nationwide acceptance and recognition of programmes by employing bodies. A popular approach has been to set up a «central institution» responsible for establishing guidelines, standards and content. Accreditation of programmes by the profession itself (e.g., Ontario) seems to have particularly high value in terms of the acceptance by the participants. Therefore, it seems advisable that recognition, approval and control be shared between the state and the profession. Here, another trend is that provision is then offered by several providers. This enables training and development to be more flexible and adaptable to participants' needs.

To sum it up, across the countries there is a developing trend in which responsibility for designing goals and programmes, and assuring quality lies with a central institution, whilst delivery is decentralized. 


\section{Preparatory training and development}

Another shift observed in the international comparison concerns the target group and the timing of the qualification in the participants' career. In more than half of the countries included in the study, development opportunities are scheduled before taking over school leadership. These countries offer pre-service preparation instead of relying solely on in-service training. Moreover, the programmes differ as to whether they are optional or mandatory (see Table 3).

Table 3. Timing in Participants' Career and Nature of Participation

\begin{tabular}{|c|c|c|c|c|}
\hline & \multicolumn{2}{|r|}{ Preparatory } & \multicolumn{2}{|r|}{ Induction } \\
\hline Mandatory & A & $\begin{array}{l}\text { Ontario, Canada; } \\
\text { USA; } \\
\text { France; } \\
\text { Singapore }\end{array}$ & B & $\begin{array}{l}\text { Germany*; } \\
\text { Austria; } \\
\text { Switzerland*; } \\
\text { South Tyrol; } \\
\text { Hong Kong }\end{array}$ \\
\hline Optional & C & $\begin{array}{l}\text { England and Wales; } \\
\text { Netherlands; } \\
\text { NSW, Australia; } \\
\text { New Zealand }\end{array}$ & $\mathrm{D}$ & $\begin{array}{l}\text { Denmark; } \\
\text { Sweden; } \\
\text { Germany*; } \\
\text { Switzerland* }\end{array}$ \\
\hline
\end{tabular}

* Double listing due to differences in the approaches of the German "Laender» or Swiss "Kantone»

In countries that have mandatory preparation (see Table 3, Cell A), taking part in the programme is an important selection criterion for future employment as a school leader. For example, France has a unique interrelation of selection, training, and appointment. Here, successful completion of the competitive "Concours» makes it possible to participate in the state-financed training. The state training is a pre-condition for employment in a leadership position. Subsequently, retaining one's post as a school leader depends on having successfully completed the second phase of qualification, the "Formation d'Accompagnement». In Singapore, the government has mandated specific career regulations. It is only possible to obtain a leadership post after taking part in state-financed, full-time training. This is offered through a single institution. The situation of teachers aspiring to school leadership in North America is less certain. Preparation is a precondition for application. However, successful completion of a preparation programme and subsequent certification does not automatically guarantee employment in a leadership position.

In countries where preparation programmes are optional (see Cell C), there is a tendency among employing bodies towards expecting some preparation for the position. An alternative trend finds the provision of in-service training immediately after appointment and before taking over the leadership position. This is the case in Hong Kong or in some States in Germany.

What are the arguments in favour of preparatory qualification? First a preparatory training and development is supposed to respond best to the rele- 
vance of school leadership. On one hand, the key role of school leaders is increasingly accepted internationally. On the other hand, pressure has increased on policymakers to ensure that the occupants of these positions can fulfil system expectations. Second, adequate preparation may reduce the "practice shock" experienced by new entrants to the role (Storath, 1995). Particularly if pre-service learning and reflection is combined with practical experiences at school, new school leaders get the chance to develop a new perspective when changing from "teaching" to "management». Third, pre-service training offers the chance of assessing one's own interests and strengths. This may help leaders to make career decision more consciously. Fourth, international experiences indicate that the provision of pre-service preparation may stimulate the number of women applicants to educational leadership positions. Women may be more self-critical, and may also be less connected to influence networks that are related to employment decisions. Obviously, development opportunities are helpful in this case. Fifth, experience shows that participants who do not obtain a leadership position may still enrich the leadership resources of their schools. Sixth, the assumption that "on-the-job-training" alone is the most effective and efficient one has not adequately been empirically validated. In this context, a cost-benefit analysis - in terms of educational economy - would have to be complex and long-term.

All of these arguments clearly favour orientation and preparation opportunities $^{2}$. More and more countries are considering preparatory courses in addition to existing in-service programmes. This reflects a movement away from the concept that the school leader is nothing more than a teacher with a few extra responsibilities.

Effective school leadership requires a demanding set of attitudes, attributes, skills, knowledge and understanding. A thorough training and development starting with appropriate preparation prior to assuming the position has been recognised as undoubtedly vital. This may be regarded as a kind of paradigm shift in the view of school leadership and leadership development.

\section{Comprehensiveness of programmes}

The tendency to regard school leadership as a profession in its own has implications concerning the extent of training and development provision for school leaders. Several countries in the survey originally started with short courses of a very practical orientation. As these providers gained more experience, they extended the programmes so that the courses might "add up» into a more comprehensive package. In some cases this also reflected an effort to ground the programmes in a stronger theoretical framework (e.g., Kolb's framework of life-long learning).

These development opportunities have become quite extensive. By way of illustration, some examples are given here from North America, Europe, Asia and Australia/New Zealand (see Table 4). It is important to mention that all of the programmes listed here are preparatory, which means that they all take place be- 
fore appointment (except the offer from the Netherlands, which may also be attended after appointment). This suggests the increasing recognition of school leader professionalization.

\section{Table 4. Length of School Leader Preparation Programmes (Contact Time)}

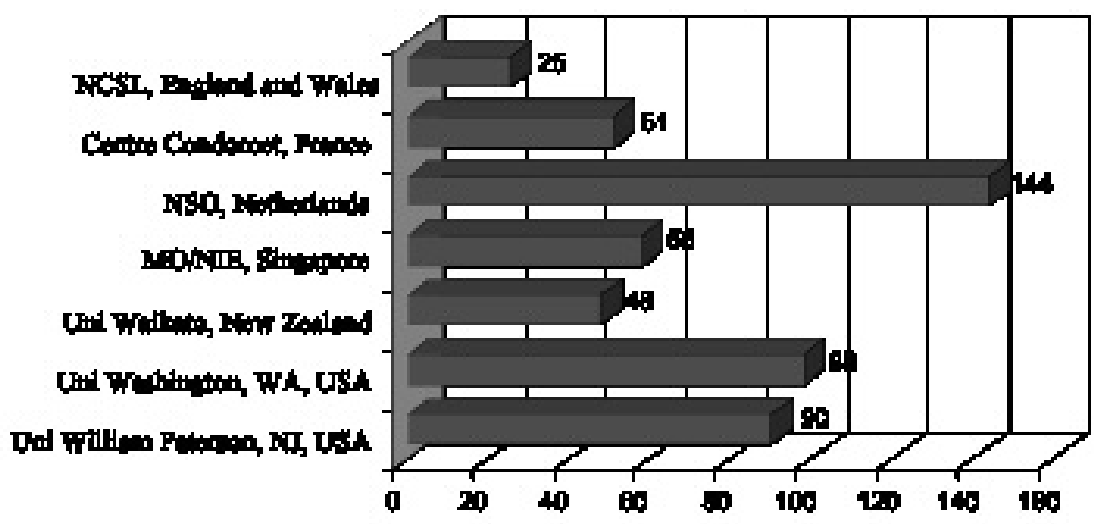

Whilst Table 4 indicates only the number of course days, the real demands on the time of the participants is apparent when we consider that beyond «contact time» there is other time committed to preparation. This includes individual study time for readings and writing assignments, but moreover time for internships or school-based projects, and the documentation of one's progress and reflection as by writing a «learning journal».

For example, at the University of Washington, preparation requires 39 credit hours (assuming 15-week semesters) and an additional 720 internship hours (i.e., 16 hours per week). The programme of the Nederlandse School voor Onderwijsmanagement is comprised of four semesters with around 350 working hours for each semester. This includes for each semester: 20 hours for seminars, 175 hours for training sessions, up to 20 hours for consultation sessions, further time for literature studies, and 140 hours for internships in the first three semesters, and time for a written assignment in the fourth semester. The University of Waikato offers a programme, comprised of 24 credit hours (assuming 12-week semesters). In addition there are 1.600 hours assumed by the provider for individual studies, participation in an email-forum and for conducting school-based projects.

In summary, there is a clear trend towards requiring an extensive set of quite time-consuming preparatory activities prior to assuming positions of leadership responsibility in schools across the countries included in this study. 


\section{Multi-phase designs and modularisation of programmes}

The international comparison shows that school leader development is more and more regarded as a continuous process. This could be divided into several phases:

- Orientation phase: This provides the opportunity for teachers interested in leadership positions to reflect on the role of a school leader in respect to their own abilities and expectations.

- Preparation phase: This occurs prior to taking over a school leadership position or even before applying for it.

- Induction phase: After taking over a leadership position, development opportunities are provided to support the school leader in her/his new position.

- Continuous development phase: This provides various training and development opportunities for established school leaders, best tailored to their individual needs and those of their schools.

Considering that raising the levels of knowledge and modifying the behaviour of participants requires a serious commitment of time, providers are increasingly moving towards several phases of development. This is resulting in the implementation of multi-phase development models, whose individual phases are well co-ordinated. Multi-phase development in this sense does not merely mean the existence of pre-service and in-service training options offered by the same provider. Genuine multi-phase development models are designed so that the different phases are well-coordinated and match with each other. They are based on a coherent conceptual approach.

In England and Wales the development model is comprised of three phases (cf. Tomlinson). First, the National Professional Qualification for Headship (NPQH) is a preparatory programme for aspiring heads. Second, the Headteacher Leadership and Management Programme (HEADLAMP) addresses the needs of newly appointed school leaders. Third, the Leadership Programme for Serving Headteachers (LPSH), is a programme for school leaders who have served for more than six years. The overall conceptualization of this three-phase programme as well as the content design within each phase represent good examples of the multi-phase model. Other providers in different countries offer similar approaches. For example, in the US, the California School Leadership Academy offers a combination of programmes that fit various stages in the career cycle of participants; in New South Wales, the Department of Education has developed a «five-phase development programme», also trying to meet different needs.

There is also a trend towards providing professional development through a series of modules. This takes two general forms. In the first form, the models are conceived of as a mandatory sequence of «rounded» single programmes. In the second form, there is no specific sequence for completing the modules. Rather participation in the modules depends on the professional position and development needs of the individual participant. The modules may be "collected» in a 
kind of personal portfolio. The individual school leader may well fall back upon them as support in crucial career phases.

Consequently, there is a tendency away from "one-size for all» designs and towards programmes tailored for the individual participant. The basic idea is that an adequate qualification cannot be completed in one pass through a standardised training programme. Instead, there is an increasing trend towards development linked to the career cycle and to specific needs of the leader, both: personally and school context-related. Table 5 shows some of the ideal type school leader development models in regard to phasing.

Table 5. Phased Models of School Leadership Development

\begin{tabular}{l|l|l|l|l|} 
& Orientation & Preparation & Induction & $\begin{array}{l}\text { Continuous } \\
\text { Development }\end{array}$ \\
\hline $\begin{array}{l}\text { One size } \\
\text { for all } \\
\text { On-the-job }\end{array}$ & & & &
\end{tabular}

From administration and maintenance to leadership for improvement

Changes in the provision of development programmes also affect contents. In spite of the increased strain on school leaders due to task overload by additional administrative responsibilities - particularly in countries with more decentralised school systems - school leader development has not become dominated by administrative issues. On the contrary, its overall focus is no longer on administrative and legal topics, but has shifted to a focus on leadership and school improvement. The emphasis has clearly shifted towards the human dimensions of leading schools.

As communication and cooperation play an essential role in school leadership, this is mirrored in the choice of contents and methods. First, in the context of "communication", one finds module titles such as leading conferences and meetings, leading a professional dialogue, problem- and conflict-solving, and creating structures of relation and communication. In the context of «co-operation», it is about gaining the co-operation of all stakeholders, creating a shared vision, a 
shared school programme, shared leadership (in the sense of spreading responsibility), and team work.

It is no longer the primary aim of school leadership to make the school function within a fixed legal framework. Today schools and their leaders must respond to the challenges of social, cultural and economic change. Schools are more and more viewed systemically as learning organizations, each with their own specific conditions, rules, and cultures. Consequently, leading schools entails developing learning organizations (Senge, 1990; Fullan 1993, 1995).

This paradigm shift from managing and maintaining to leading and improving schools is mirrored in the themes of many development programmes reviewed in this study. For example, Danish and Canadian programmes place educational leadership explicitly in the context of school change. They view the school leader as a first class «change agent».

In many programmes, similar themes are evident within the areas of school development and staff development. Examples include: school as a learning organization, culture of an organization, psychology of organizations, school quality and development of quality, setting up a vision and implementing the vision, management of school programmes, initiating and implementing change, school improvement projects, project management, leading and developing staff, allocation of staff, teamwork and team development, in-service-training for staff, staff development and teachers' supervision.

The topic of evaluation and quality assurance also plays an important part within this broader theme: school evaluation, methods of evaluation, internal and external evaluation, appraisal and assessment of pupil achievement, accountability, action research and evaluation, organizational learning and evaluation, supervision and evaluation.

The international comparison shows quite conclusively that these development programmes have shifted towards a focus on the role of leadership for improvement. Within this role, the central task is the development of the school in cooperation with all stakeholders. The conception of school leadership as administration of the status quo has to a high degree given way internationally to a new conception of school as a learning organization and of its leadership as a driving force and safeguard of effective improvement processes.

\section{Developing the leadership capacity of schools}

One tendency suggested above that may be developing into a paradigm shift is the conceptualisation of school as a «learning organization». This conceptualization also shifts the focus away - somewhat - from the development of the individual school leader to the development of each individual school's leadership capacity. Hence, the school leadership development programme becomes a means of school development.

With this in mind, some providers explicitly have changed their programmes and have widened their target groups. They focus not only on (aspiring) school 
leaders, but also on teachers who want to enhance their leadership competencies even if they are not planning to apply for school leader positions. This is the case, for instance, in New Jersey and New South Wales. If school development is the explicit goal, programmes may target whole school leadership teams (e.g., the Danish programme Leadership in Development), and may include parent and community representatives. The California Leadership Academy has programmes that target established leadership teams from schools. While the trend towards team-based training is only apparent in a few programmes, an increasing number of providers state that they intend to focus on developing leadership teams. They express the belief that this approach is necessary in order to establish stronger leadership and change capacities within schools.

As an additional note, this new focus on developing team leadership capacity suggests a shift towards focusing on the individual school rather than the individual participant. This has interesting implications for programme content. When a programme focuses on a team, development activities must become even more contextualized: It is no longer context-free training, but context-specific applied development.

\section{From acquisition to creation and development of knowledge}

In many programmes, two considerations seem increasingly to be taken into account: First, when rapid social and economic change and changes in the educational system are coupled with a global increase in information production, it is insufficient for programmes to focus solely on enlarging the quantity of leaders' knowledge. The qualification must prepare for an unknown future environment. This suggests still another paradigm shift. It is a shift away from imparting a stable knowledge base and towards the development of procedural knowledge that can be applied. The notion of «acquiring» knowledge is being replaced by the concepts of «developing» or "creating» knowledge and by information management. The participants will enhance their ability to learn, understand cognitive processes and achieve what is called "conceptual literacy» (see Giroux, 1988). They have to be enabled to act in a complex, sometimes chaotic work environment (see Murphy, 1992).

Second, there is consensus that delivery methods must address the learning needs and competences of adult learners. Hence, fundamental andragogic principles must be taken into account. This reflects the belief that new knowledge is built on previous experiences and the knowledge of the adult learners. Adults bring personal and professional experiences, prior knowledge, and their own personal ways of seeing themselves to bear on the learning process to a greater degree than children (see Siebert, 1996). Themes that cannot be linked to previously existing cognitive systems are mostly forgotten. The reality and the experiences of the participants, their needs and problems, should therefore become the starting point of new learning. Consequently, methods of learning 
tend to favour a problem-centred rather than theme-centred approach. According to Gruber (2000), gaining experience for professional competences means learning in complex application-relevant and practice-relevant situations (see also Joyce \& Showers, 1988/1995). New competences are mostly gained in a process of practice and feedback. For this, sufficient theoretical foundations should be imparted as well in order to foster reflection on practice.

In many development programmes there is a clear tendency towards experience-oriented and application-oriented methods. Indeed, methods of learning and processing of information are apparent as programme themes as well, either implicitly or explicitly. There is a shift of emphasis in school leader development towards practice-with-reflection-oriented learning. This can be seen in the attempt to bring practical work experiences from the schools to bear during the programmes through cases, learning journals, and discussion groups.

Moreover, increasingly the participants are placed in a workshop surrounding, and confronted with modelled situations of school leadership work life and carefully constructed cases. They may be involved in teams in problem-based learning (PBL) where learning is cooperative, interactive, participative, and, to a certain degree, group- and self-organised. More consequently than the case studies and simulations often applied in development programmes, the PBL approach starts with real-life experiences and then looks for supportive knowledge as a tool. The slogan here is: "First the problem, then the content.» (Bridges \& Hallinger, 1995, p. 8). Here, the problem is seen as a stimulus for learning that then leads to the content required to solve it. Problem-based learning has become a consistent part of a number of programmes for school leaders internationally (e.g., at the University of Washington). It is meant to offer a greater practical relevance and thus addresses the theory vs. practice conflict. Within $\mathrm{PBL}$, team learning is especially critical in order to achieve solutions to problems. Problem-solving is an interactive participative process.

Certainly, problem-based learning is an interesting attempt to get practice relevance by using concrete problems taken from real life. Yet in PBL, the problem remains constructed and imagined. This surely has advantages: However close to the complexity of school leadership reality the constructed problem may be, it always remains consciously designed and structured enough to enable exemplary learning experiences.

Going one step further means using genuine cases that are taken from real schools, either from the schools of the participants or from partnership schools. Within this approach, participants of the project group become external counsellors for the leaders of these schools. Through this interaction both parties benefit. This method is, for example, used by York University via an online conference system. Two experienced school leaders present a problem every seven to ten days, taken from their work life, to the group of which they are in charge.

Some development programmes take another step further, leave the workshop and turn to the authentic workplace, using it as a clinical faculty. It is ar- 
gued that only the authentic working context can assure an adequate complexity and authenticity leading to learning processes required. For the participants of pre-service school leader development, internships at one school or several schools are organized parallel to the training. They can observe the school leader by shadowing her/him, can partially take over leadership tasks themselves, and can carry out projects independently. The school leaders at the internship schools then function as mentors or supervisors and will also benefit from this co-operation. In general, new partnership arrangements between universities, other providers of school leadership development, and schools are an important basis for learning opportunities like these. Thus, certainly the best possible practice relevance is created: Exemplary learning processes take place in the reality of school (cf. Littky \& Schen).

As Huber and West (2002) show, the training provision can be conceptualised as being spread across two continua of course-based and experience-based learning opportunities. Hence, it is possible to distribute the programmes worldwide according to the relative emphasis given to these two strategies (see Table 6).

\section{Table 6. Emphasis of Learning Opportunities within School Leader Development Programmes 3}

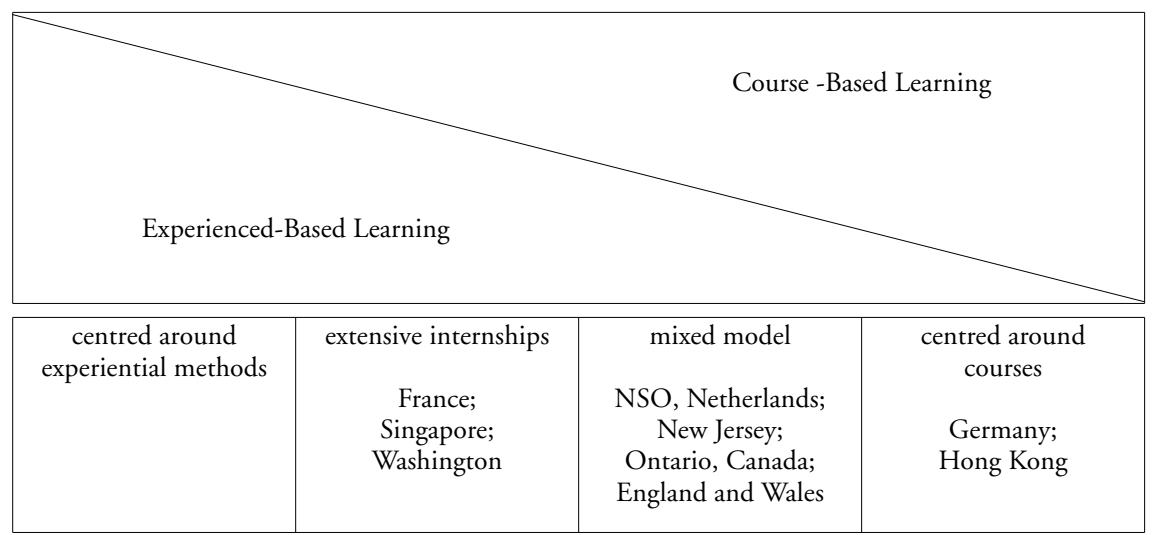

Project work and/or internships are included, for example, in the National Professional Qualification for Headship in England and Wales, in the Managementen Organisatieopleidingen of the Nederlandse School voor Onderwijsmanagement, in the Master programme in Educational Leadership at the William Paterson University of New Jersey, in the Principal's Qualification Programme in Ontario, and particularly extensive in the central programme in France, in the Diploma in Educational Administration in Singapore, and in the Danforth Educational Leadership Programme at the University of Washington. However, countries which still favour more or less an approach to leadership development 
which is centred around courses also indicate that certain modifications are under consideration.

Hence, it is obvious that in many countries there is a shift from solely coursebased learning towards experience-based learning in development programmes. Increasingly, programmes are centred around experiential methods.

\section{From role-based training to personal and professional development}

Within this era of constant change, it is no longer sufficient to train participants for a fixed role. For some observers this suggests the need to focus on basic professional values, beliefs and concerns of school leaders. This demands that (aspiring) school leaders reflect upon their own conceptions of schools and the role of a school leader.

Following this line of thinking, programmes offered in many countries include components such as personal vision, personal and professional development, development of fundamental values, reflective practice, «cognitive mapping»-strategies in terms of working with one's own mental pictures of one's school, and time- and self-management. This results in a shift from focusing on a specific role to looking at personal and professional needs within a complex setting. Programmatically there is a shift from «providing training to someone» to "offering development opportunities for someone». Therefore, the individual school leader is put in the centre by focusing her/his personal development, and a former fixed set of contents or a traditional curriculum are pushed into the background.

\section{New Leadership conceptions}

Changes in the schools and their context also have some impact on the role of school leaders. This new role can hardly be filled with old concepts of leadership. School leader development has to take this into account. Consequently, some of the development programmes relate to new and quite specific leadership conceptions.

As schools are no longer seen as static systems, conceptions like «transformational leadership" are becoming more popular. Transformational leaders view school as a culturally independent organism that is able to develop. Hence, they exercise an active influence on the culture of the school. They are not only expected to manage structures and tasks, but to concentrate on people and their interpersonal relationships. They make an effort to win their cooperation and commitment. Leadership of this type is considered more suitable for the tasks of school development (see Leithwood, 1992).

If school is to become a learning organization, this implies the active empowerment and cooperative commitment of all stakeholders. Then, the previous division between the positions of teachers on one hand and learners on the other hand cannot be maintained. Nor can the division between leaders and followers. 
Leadership is no longer statically linked to the hierarchical status of an individual person, but empowers as many staff members as possible as partners in various parts. This is conceptualised by the notion of "post-transformational leadership" (see Jackson \& West, 1999).

Another concept, for example, is «integral leadership». It views school leaders primarily as leaders with genuinely educational tasks and emphasizes an integrating perspective, which overcomes the divide of management and leadership for the sake of the educational aims of schools (see Imants \& de Jong, 1999).

\section{Final Remarks: Leadership, Values, and the School's Core Purpose}

The comparison of school leader development in these 15 countries gives a dominant impression of global approaches and shifts. What can be clearly stated about school leader development from this international perspective is that there were many changes during the last years in nearly every country. It is apparent that a number of countries have acted more actively than others. In some countries, school leader development opportunities have improved particularly during the last 10 years. However, there is still some way to go.

One issue seems particularly interesting: Increasingly the programmes are organized around new conceptions of schooling. The old notion of the school as an unchanging, maintaining and very static organization is no longer suitable. Increasingly, schools are seen as learning, problem-solving, creative, self-renewing or self-managing organisations.

If change is on the agenda of schools and school leaders, it is crucial to have a vision which gives them a direction. Leaders (of any kind) need to know which are the goals and aims for real improvement (and not change for its own sake). Basically, what is needed is to have criteria to judge the overall leadership approach and the day-to-day decision making. This should be back-mapped against the core purpose of school.

In some countries, this notion was taken into account when designing school leader development. The schools' core purpose - namely teaching and learning and the specific current and future aims of schools have increasingly left their traces in the concepts of various development programmes. The principle that a "school has to be a model of what education aims at" (Rosenbusch, 1997) thus has consequences not only for defining the role of school leaders but also for the design of development programmes.

As a solid base for what education aims at, in some of the programmes an orientation towards a specific value-based attitude is intended. Thus, the understanding of leadership in this context includes moral and political dimensions. Leadership in a democratic society emphasizes values such as equality, justice, fairness, welfare and a careful use of power. In the compilations of topics, the role 
of values, ethics and morals, the question of power, and how to legitimate leadership in a democracy and for social justice are increasingly central themes. This holds true, for example, for the programme of Danmarks Paedagogiske Universitet and that of the University of Waikato, New Zealand (both doing without any state guidelines), but also in the standards- or guidelines-oriented programmes of the US examples, Canada, and some others.

This comparison indicates certain current trends and contributes to the discussion in the field, yet there is still much to be done. For example, there still is an obvious lack of analyses of the training and development needs of school leaders in the different stages of their careers. Moreover, the quality and the effectiveness of school leader development programmes have to be evaluated. Further internationally in-depth comparative studies to identify best practice have to be conducted. Very important is to establish networks, which could provide further co-operation and collaboration between those planning and providing school leadership development and those conducting research in different countries.

\section{Notes}

1 The term «school leader» is in this chapter used instead of principal, headteacher, administrator, rektor or other terms describing the person who is in charge of an individual school.

2 Even more extensive are approaches to make orientation elements for leadership part of initial teacher training in order to identify and foster potential for leadership at the earliest possible stage. This has been done recently by the Australian State of Victoria. In Sweden, there is a project that offers enrolment in a school management course during initial teacher training, and in Canada, too, long-term promotion is intended by a portfolio-system.

3 It has not been taken into account whether the offers are made to teachers aspiring to leadership or to school leaders newly appointed and in position. Besides, the different emphasis could be viewed in reference to the total amount or length of training available; since offering experiential learning opportunities inevitably means expanding the programme accordingly.

\section{References}

Bridges, E. \& Hallinger, P. (1995). Implementing problem-based learning in leadership development. Eugene, OR: ERIC Clearinghouse on Educational Management.

Fullan, M. (1993). Change forces. London: Falmer Press.

Fullan, M. (1995). Schools as learning organizations: Distant dreams. Theory into Practice, 34 (4), 230-235.

Giroux, H. A. (1988). Teachers as intellectuals: Toward a critical pedagogy of learning. Granby, MA: Bergin \& Garvey.

Gruber. (2000). Erfahrung erwerben. In C. Harteis, H. Heid \& S. Kraft (Hrsg.), Kompendium Weiterbildung (S. 121-130). Opladen: Leske + Budrich.

Huber, S. G. (2002). Qualifizierung von Schulleiterinnen und Schulleitern im internationalen Vergleich. Innsbruck: Studien Verlag.

Huber, S. G. (2003). Preparing school leaders for the 21st century: An international comparison of development programs in 15 countries. London/New York: Routledge/Falmer (Taylor \& Francis). 
Huber, S.G. \& West, M. (2002). Developing school leaders: A critical review of current practices, approaches and issues, and some directions for the future. In K. Leithwood \& P. Hallinger (Eds.), International handbook of educational leadership and administration. Dordrecht: Kluwer Academic Press.

Imants, J. \& de Jong, L. (1999, January). Master your school: the development of integral leadership. Paper presented at the International Congress for School Effectiveness and Improvement, San Antonio, Texas.

Jackson, D. \& West, M. (1999, January). Leadership for sustained school improvement. Paper presented at ICSEI, San Antonio, Texas.

Joyce, B. \& Showers, B. (1988/1995). Student achievement through staff development. New York: Longman.

Leithwood, K. A. (1992). The move toward transformational leadership. Educational Leadership, 49 (5), 8-12.

Murphy, J. (1992). The landscape of leadership preparation: Reframing the education of school administrators. Newbury Park, CA: Corwin Press.

Rosenbusch, H. S. (1997). Organisationspädagogische Perspektiven einer Reform der Schulorganisation. Schul-Verwaltung, 10, 329-334.

Senge, P. (1990). The fifth discipline. New York: Doubleday.

Siebert, H. (1996). Didaktisches Handeln in der Erwachsenenbildung: Didaktik aus konstruktivistischer Sicht. Neuwied: Luchterhand.

Storath, R. (1995). "Praxisschock» bei Schulleitern. Eine Untersuchung zur Rollenfindung neu ernannter Schulleiter. Neuwied: Luchterhand.

Key words: Leadership, Quality, Development, Improvement

\section{Internationale Tendenzen in der Schulleitungsqualifizierung}

\section{Zusammenfassung}

Die Bedeutung der Schulleitung für die Qualität und Entwicklung der Schule wird zunehmend erkannt, und die Investitionen in die Qualifizierung von pädagogischen Führungskräften nehmen zu. Wie aber gestalten andere Länder die Qualifizierung ihres Schulleitungspersonals? In dem Beitrag werden Ergebnisse einer Vergleichsstudie von Schulleitungsqualifizierung in 15 Ländern des europäischen, nordamerikanischen, asiatischen und australischen Raumes vorgestellt und internationale Entwicklungstendenzen beschrieben. Deutlich wird, dass den Zielsetzungen der Qualifizierungsprogramme eine Führungskonzeption zugrunde liegen sollte, die der zentralen Aufgabe der Schule und pädagogischen Prämissen explizit entspricht.

Schlagworte: Pädagogische Führung, Qualität, Entwicklung, Verbesserung 


\title{
Qualification des directeurs d'établissements scolaires: les tendances actuelles dans une perspective internationale
}

\author{
Résumé \\ Cet article porte son attention sur l'intérêt croissant suscité par les initiatives \\ orientées à préparer les directeurs d'établissement à leur rôle central pour déve- \\ lopper et pour assurer la qualité de l'école et pour gérer les responsabilités crois- \\ santes auxquelles ils sont confrontés. Dans plusieurs pays, cela a conduit à la dé- \\ finition et l'implémentation de programmes d'envergure. Cet article proposera \\ un survol général des principales approches appliquées en Europe, Asie, Océanie \\ and Amérique du Nord et relèvera les tendances internationales concernant la \\ qualification des directeurs. Il apparaîtra évident que la qualification des direc- \\ teurs devrait se fonder sur une compréhension élargie du leadership dans le do- \\ maine de l'école et se baser sur des convictions éducatives qui intègrent les va- \\ leurs d'une société démocratique.
}

Mots clés: Leadership, professionalisation de la direction d'école, qualité et dévelopement de l'école

\section{Formazione dei direttori d'istituti scolastici: tendenze attuali in una prospettiva internazionale}

\section{Riassunto}

Questo articolo si concentra sull'interesse crescente suscitato da iniziative volte a preparare i direttori d'istituti scolastici al loro ruolo centrale per sviluppare e assicurare la qualità della scuola e per gestire le crescenti responsabilità alle quali sono confrontati. A questo proposito, in numerosi paesi, si è giunti alla definizione e all'implementazione di vasti programmi. L'articolo proporrà una presentazione generale degli approcci principali presenti in Europa, Asia, Oceania e Nordamerica e rileverà le tendenze internazionali riguardanti la formazione dei direttori d'istituto. L'articolo permetterà di sottolineare come la formazione dei direttori dovrebbe fondarsi su una comprensione approfondita della leadership in campo scolastico e basarsi su convinzioni educative che integrino i valori di una società democratica.

Parole chiave: leadership, qualità, sviluppo, miglioramento 